\title{
EFFECT OF ETHANOL EXTRACT OF CHAYOTE (Sechium Edule Jacq. Swartz) ON INSULIN RESISTANCE IN RAT WITH DIABETES MELLITUS TYPE 2 INDUCED BY STREPTOZOTOCIN-NICOTINAMIDE-HIGH FAT DIET
}

\author{
Jekson Martiar Siahaan',2), Syaffrudin Illyas3), \\ Dharma Lindarto4), Marline Nainggolan5)
}

\begin{abstract}
1)Post Graduate Student of Doctoral Program, Faculty of Medicine, Universitas Sumatera
Utara ${ }^{2)}$ Department of Physiology, Faculty of Medicine, Universitas Methodist, Medan

3)Department of Biology, Faculty of Mathematics and Natural Science, Universitas Sumatera Utara

4)Department of Internal Medicine, Faculty of Medicine, Universitas Sumatera Utara

5)Department of Biological Pharmacy, Faculty of Pharmacy, Universitas Sumatera Utara
\end{abstract}

\begin{abstract}
Background: Insulin resistance has important role in the pathogenesis of several diseases, including diabetes. Recent study showed that oxidative stress and chronic inflammation are involved in the pathophysiology of diabetes mellitus. Harmless antioxidant and anti-inflammatory therapeutic alternatives have been proposed, for example, the consumption of Sechium Edule Jacq. Swartz (chayote). This study aimed to determine the effect of ethanol extract of chayote (Sechium Edule Jacq. Swartz) on insulin resistance in rat with diabetes mellitus type 2 induced by STZ-NA-HFDD.

Subjects and Method: This was a randomized controlled trial posttest only with control group design. A sample of 44 rats was selected for this study at random, divided into 11 groups. Doses of ethanol extract of squash divided in 3 categories including: $45 \mathrm{mg} / \mathrm{kgBW}, 100 \mathrm{mg} / \mathrm{kgBW}$ and $150 \mathrm{mg} / \mathrm{kgBW}$. The independent variable was ethanol extract of chayote. The dependent variables were blood sugar level, malondialdehyde (MDA), Superoxida Dismutase (SOD), and HOMA-IR. Differences in mean between groups were tested by One Way ANOVA and post hoc test.

Results: The mean differences of blood sugar level were not statistically signi $\neg$ ficant ( $p=0.525$ ), with the lowest level of blood sugar level was in $45 \mathrm{mg} / \mathrm{kgBW}$ ethanol extract of chayote group (Mean=155.16; $\mathrm{SD}=31.92)$. The mean differences of MDA level were statistically significant $(\mathrm{p}=0.001)$, with the highest MDA level was in $100 \mathrm{mg} / \mathrm{kgBW}$ ethanol extract of chayote group (Mean $=1.40 ; \mathrm{SD}=0.23$ ). The mean differences of insulin resistance level were not statistically significant $(\mathrm{p}=0.071)$, with the lowest insulin resistance level was in $45 \mathrm{mg} / \mathrm{kg}-\mathrm{BW}$ ethanol extract of chayote group (Mean= 0.16 ; $\mathrm{SD}=0.08$ ). The mean differrences of level of superoxide dismutase were not statistically significant ( $\mathrm{p}=0.525$ ), with the highest level of superoxide dismutase was in $45 \mathrm{mg} /$ $\mathrm{kgBW}$ ethanol extract of chayote group (Mean=1.10; $\mathrm{SD}=0.75)$.

Conclusion: The low dose ( $45 \mathrm{mg} / \mathrm{kgBW}$ ) of chayote ethanol extract can effectively lower blood sugar, oxidative stress, and insulin resistance level. The $100 \mathrm{mg} / \mathrm{kgBW}$ dose of chayote ethanol extract can effectively increase MDA.
\end{abstract}

Keywords: blood sugar, insulin resistance, oxidative stress, malondialdehyde, chayote ethanol extract.

\section{Correspondence:}

Jekson Martiar Siahaan. Post Graduate Student of Doctoral Program, Faculty of Medicine, Universitas Sumatera Utara, Medan, North Sumatera. Email: jekson.siahaan.sked@gmail.com. Mobile: +6289666444206.

The $6^{\text {th }}$ International Conference on Public Health Best Western Premier Hotel, Solo, Indonesia, October 23-24, 2019 | 340 https://doi.org/10.26911/the6thicph.05.05 